\title{
Bdellovibrio exovorus sp. nov., a novel predator of Caulobacter crescentus
}

\author{
Susan F. Koval, ${ }^{1}$ Sandra H. Hynes, ${ }^{1}$ Ronald S. Flannagan, ${ }^{1} \dagger$ \\ Zohar Pasternak, ${ }^{2}$ Yaacov Davidov ${ }^{2}$ and Edouard Jurkevitch ${ }^{2}$ \\ ${ }^{1}$ Department of Microbiology and Immunology, University of Western Ontario, London, \\ ON N6A 5C1, Canada \\ ${ }^{2}$ Department of Plant Pathology and Microbiology, The Hebrew University of Jerusalem, PO Box 12, \\ Rehovot 76100, Israel
}

Correspondence

Susan Koval

skoval@uwo.ca

\begin{abstract}
The life cycle, prey range and taxonomic status of a Bdellovibrio-like organism, strain JSS ${ }^{\top}$, were studied. Strain $\mathrm{JSS}^{\top}$ was isolated from sewage in London, Ontario, Canada, in enrichment culture with Caulobacter crescentus prey cells. During predation, this strain remained attached to the outside of a stalked C. crescentus cell. No periplasmic growth stage was observed and no bdelloplast was formed. The stalked cells of $C$. crescentus retained their shape and, after predation, were devoid of cytoplasmic content, as shown by transmission electron microscopy. A periplasmic growth stage has been a definitive character in the description of members of the genera Bdellovibrio, Bacteriovorax, Bacteriolyticum and Peredibacter. This is the first description of an epibiotic predator in this group of prokaryotic predators. The $\mathrm{G}+\mathrm{C}$ content of the genomic DNA of strain $\mathrm{JSS}^{\top}$ was 46.1 mol\%. 16S rRNA gene sequence analysis showed that this strain was related to Bdellovibrio bacteriovorus strains $\mathrm{HD}_{100^{\top}}, 109 \mathrm{~J}, 114$ and 127 (90-93\% similarity). Phylogenetic analysis based on $16 \mathrm{~S}$ rRNA gene sequences grouped strain $\mathrm{JSS}^{\top}$ with the Bdellovibrio cluster, but at a distance from other Bdellovibrio isolates. On the basis of features of the life cycle and phylogenetic data, it was concluded that strain $\mathrm{JSS}^{\top}$ merits classification as the type strain of a novel species, for which the name Bdellovibrio exovorus sp. nov. is proposed

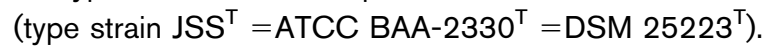

Bdellovibrio bacteriovorus is a small, rapidly motile, Gramnegative bacterium that is an obligate predator of other Gram-negative bacteria. It has a life cycle characterized by a free-living, non-replicating attack phase and a reproductive phase within the periplasm of the prey cell. The first report of Bdellovibrio bacteriovorus described the isolates as predatory, ectoparasitic and bacteriolytic micro-organisms (Stolp \& Starr, 1963). Subsequent studies by Starr \& Baigent (1966) and Burnham et al. (1968) described prey cell penetration and the intraperiplasmic growth of the parasite. For many years, new isolates of predatory bacteria were assigned to the genus Bdellovibrio, as strains of Bdellovibrio bacteriovorus, based

This paper is dedicated to R. G. E. Murray, for his contributions to systematics.

tPresent address: Program in Cell Biology, The Hospital for Sick Children, Toronto, ON M5G 1X8, Canada.

Abbreviation: BALO, Bdellovibrio-and-like organism.

The GenBank/EMBL/DDBJ accession number for the 16S rRNA gene sequence of strain $\mathrm{JSS}^{\top}$ is EF687743.

Two supplementary figures are available with the online version of this paper. on their morphological characteristics (comma-shaped rods; motile by means of a single, polar, sheathed flagellum) and predatory life cycle. Seidler \& Starr (1969) reported the DNA G $+C$ contents of 11 isolates of prey-dependent bdellovibrios and noted that two isolates of uncertain nomenclature status had $\mathrm{G}+\mathrm{C}$ contents of $\sim 43 \mathrm{~mol} \%$, less than that of all other isolates, which had $\mathrm{G}+\mathrm{C}$ contents of $\sim 50 \mathrm{~mol} \%$. Two novel species were described by Seidler et al. (1972): Bdellovibrio starrii (the $\mathrm{A} 3.12^{\mathrm{T}}$ isolate from the original work of Stolp and Starr) and Bdellovibrio stolpii (the $\mathrm{UKi} 2^{\mathrm{T}}$ isolate from the Conti lab). These two species were subsequently transferred to a new genus, Bacteriovorax (Baer et al., 2000), and then each to other new genera, as Peredibacter starrii (Davidov \& Jurkevitch, 2004) and Bacteriolyticum stolpii (Piñeiro et al., 2008). Collectively, Bdellovibrio, Bacteriovorax, Bacteriolyticum and Peredibacter species and strains and taxonomically uncharacterized isolates of intraperiplasmic, predatory prokaryotes are referred to as 'Bdellovibrio-and-like organisms' (BALOs) (Snyder et al., 2002). As predators, BALOs have been defined as having a cell cycle featuring an obligate, intraperiplasmic developmental stage inside the substrate bacterium (Jurkevitch, 2006). 
In a study on the protective function of paracrystalline protein surface layers (S-layers) against predation by Bdellovibrio bacteriovorus (Koval \& Hynes, 1991), we isolated on Caulobacter crescentus CB2A, a predatory bacterium, strain $\mathrm{JSS}^{\mathrm{T}}$, which resembled Bdellovibrio bacteriovorus in many respects. This BALO is a small, motile, comma-shaped rod that possesses a single, polar, sheathed flagellum (29 nm wide) (Koval \& Hynes, 1991). It is a prey-dependent predator that forms plaques on lawns of $C$. crescentus. In the present study, we report further characterization of strain $\mathrm{JSS}^{\mathrm{T}}$ and provide evidence for the description of a novel species of Bdellovibrio.

Initial studies on the growth of strain JSS $^{\mathrm{T}}$ were done in co-cultures in 1/10-strength yeast extract-peptone medium supplemented with calcium (YP/10 plus $\mathrm{Ca}^{2+}$ ) (Koval \& Hynes, 1991). This was necessary because the C. crescentus strain with an S-layer (strain CB2NY66R) was unstable in the HEPES plus $\mathrm{Ca}^{2+}$ buffer used in other co-cultures in this study. However, the S-layer-negative strain of C. crescentus (strain CB2A) (=ATCC BAA-2331 $=\mathrm{DSM}$ 25117) is stable in HEPES buffer. HM buffer [ $3 \mathrm{mM}$ HEPES ( $\mathrm{pH} 7.6$ ) with $1 \mathrm{mM} \mathrm{CaCl}_{2}$ and $0.1 \mathrm{mM}$ $\left.\mathrm{MgSO}_{4}\right]$ was used for further studies, to correlate with other studies on Bdellovibrio bacteriovorus 109J (Thomashow \& Rittenberg, 1978; Flannagan et al., 2004). Dilute nutrient broth medium (Cotter \& Thomashow, 1992) may also be used for co-cultures. For maintenance, co-cultures containing $1 \mathrm{ml}$ strain $\mathrm{JSS}^{\mathrm{T}}$ and $4 \mathrm{ml}$ of a $24 \mathrm{~h}$ peptone-yeast extract (PYE) broth culture (Johnson \& Ely, 1977; Koval \& Hynes, 1991) of C. crescentus CB2A were incubated in $125 \mathrm{ml}$ flasks with $20 \mathrm{ml} \mathrm{HM}$ buffer. The co-culture was incubated at $30{ }^{\circ} \mathrm{C}$ with shaking at 150 r.p.m. for $24-48 \mathrm{~h}$. Cultures were transferred to sterile screw-capped tubes and kept at $4{ }^{\circ} \mathrm{C}$ for up to 1 month. Cell suspensions were plated for plaques using yeast extract-peptone-acetate medium (YPSC) (Koval \& Hynes, 1991) or dilute nutrient broth medium. Plaques were small. For long-term storage, a $24-48 \mathrm{~h}$ culture of strain $\mathrm{JSS}^{\mathrm{T}}$ cells was frozen in the presence of $25 \%(\mathrm{w} / \mathrm{v})$ glycerol at $-80{ }^{\circ} \mathrm{C}$. Bdellovibrio bacteriovorus strain 109J was grown on Escherichia coli ML35 (Flannagan et al., 2004) and strain 6-5-S on Aquaspirillum serpens VHL (Koval \& Hynes, 1991). Bacteriolyticum stolpii $\mathrm{UKi}^{\mathrm{T}}$ was obtained from J. Tudor (St. Joseph's University, Philadelphia, PA, USA); it was maintained on peptone-yeast extract medium (1\% peptone, $0.3 \%$ yeast extract, $1 \%$ agar, $\mathrm{pH}$ 6.8) (Seidler \& Starr, 1969).

The C. crescentus strains used in this study are listed in Table 1 and were obtained from J. Smit (University of British Columbia, Vancouver, BC, Canada) and J. Poindexter (Barnard College, Columbia University, New York, NY, USA). All C. crescentus strains were maintained on PYE medium. Other Gram-negative bacteria used to test the prey range of strain JSS $^{\mathrm{T}}$ were from the culture collection of the Department of Microbiology and Immunology, University of Western Ontario.
Table 1. Predation of Caulobacter crescentus strains by strain JSS $^{\top}$

\begin{tabular}{|lccl|}
\hline Strain & S-layer & Predation & Source \\
\hline CB2A & - & + & J. Smit \\
CB2NY66R & + & - & J. Smit \\
CB13bla & - & + & J. Smit \\
CB15A KSAC & - & + & J. Smit \\
Rmg1 & - & + & J. Poindexter \\
A-19 & + & - & J. Poindexter \\
CB15-BE & - & + & J. Poindexter \\
\hline
\end{tabular}

The age of prey cells affected the growth of strain $\mathrm{JSS}^{\mathrm{T}}$. When C. crescentus CB2A was grown in PYE medium, cells entered late exponential phase/early stationary phase in about $10-12 \mathrm{~h}$. In co-cultures, strain $\mathrm{JSS}^{\mathrm{T}}$ grew well on prey cells grown for 8,14 and $24 \mathrm{~h}$ but, with prey cells grown for $48 \mathrm{~h}$, predation was incomplete. There were always some residual, unattacked prey cells in the coculture. Therefore, C. crescentus CB2A cells were routinely grown for $24 \mathrm{~h}$ before use.

Initial observations on the growth of strain JSS ${ }^{\mathrm{T}}$ were made by phase-contrast light microscopy, at which time the lack of intraperiplasmic growth was noted (Koval \& Hynes, 1991). Co-cultures were then examined by transmission electron microscopy. For thin sections, samples were fixed with acrolein $(5 \% \mathrm{v} / \mathrm{v})$ and glutaraldehyde $(0.25 \%$, v/v) in $50 \mathrm{mM}$ cacodylate buffer, enrobed in Noble agar and postfixed with $1 \%$ osmium tetroxide and $1 \%$ uranyl acetate. After dehydration in an ethanol series, samples were embedded in Spurr resin. Thin sections were post-stained with uranyl acetate and lead citrate. All preparations were examined in a Philips EM300 operating at $60 \mathrm{kV}$. Predators remained attached to the outside of the prey cell (Fig. 1) and did not enter the periplasmic space. At the attachment site (Fig. S1, available in IJSEM Online), a 'bulge' of prey outer membrane formed around the attached end of strain JSS $^{\mathrm{T}}$. There was a localized degradation of peptidoglycan, but the electron-dense bilayer of the prey plasma membrane remained intact (Fig. S1b). No bdelloplast-like structures were ever seen in thin sections and the prey cells did not round up after attack by strain $\mathrm{JSS}^{\mathrm{T}}$. The stalked cells retained their original shape and, at the end of predation, were devoid of cytoplasmic content (Fig. 1b). Strain $\mathrm{JSS}^{\mathrm{T}}$ is thus an example of an epibiotic predator (Davidov et al., 2006).

How do strain JSS $^{\mathrm{T}}$ cells replicate? No long, aseptate filaments (analogous to those seen inside bdelloplasts) were ever seen on the outside of prey cells by light or electron microscopy. In thin sections (Fig. 1), cells of strain JSS $^{\mathrm{T}}$ appeared to be dividing by binary fission. For analysis by scanning electron microscopy (SEM), a $20 \mathrm{ml}$ culture of strain JSS $^{T}$ was centrifuged, resuspended in $5 \mathrm{ml} \mathrm{YP/10}$ plus $\mathrm{Ca}^{2+}$ medium and added to $2 \mathrm{ml}$ of a $24 \mathrm{~h}$ culture of C. crescentus CB2A in $18 \mathrm{ml} \mathrm{YP} / 10$ plus $\mathrm{Ca}^{2+}$ in a $125 \mathrm{ml}$ side-arm flask. The co-culture was incubated at $30{ }^{\circ} \mathrm{C}$ with 


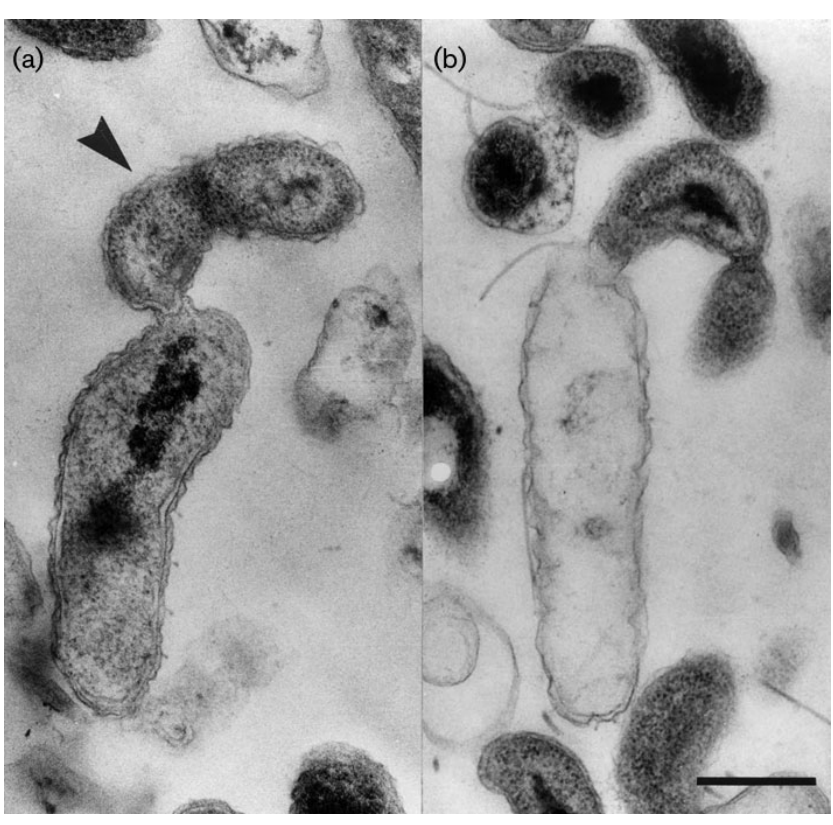

Fig. 1. Thin sections of cells of strain $J S S^{\top}$ attached to intact (a) and empty (b) stalked cells of Caulobacter crescentus CB2A. The arrowhead in (a) indicates the cell of strain $\mathrm{JSS}^{\top}$. Bar, $500 \mathrm{~nm}$. The image in (a) is reprinted from the cover of Journal of Bacteriology vol. 183 issue 11 (2001) with permission from the American Society for Microbiology.

shaking until many JSS ${ }^{\mathrm{T}}$ cells had attached to prey cells. Samples $(0.5 \mathrm{ml})$ from co-cultures were filtered through a Nucleopore $0.2 \mu \mathrm{m}$ polycarbonate filter (Millipore Corp.) in a $13 \mathrm{~mm}$ Swinney filter holder. Filters were fixed overnight in $2.5 \%$ glutaraldehyde in $0.1 \mathrm{M}$ cacodylate buffer ( $\mathrm{pH} 7.2$ ), rinsed twice in buffer, post-fixed in $1 \%$ osmium tetroxide for $1 \mathrm{~h}$ at $4{ }^{\circ} \mathrm{C}$ and then rinsed with buffer and distilled water before dehydration in a graded ethanol series. Samples were critical-point-dried with a SamDRI-PVT-3B model, gold coated and examined in a Hitachi model S-4500 field emission scanning electron microscope. Cells of strain JSS $^{\mathrm{T}}$ were seen attached to stalked prey cells (Fig. S2a), but no long filamentous extracellular forms were seen. It was concluded that strain $\mathrm{JSS}^{\mathrm{T}}$ divides by binary fission. SEM preparations confirmed the evacuation and collapse of stalked prey cells during predation (Fig. S2b).

The prey range of strain $\mathrm{JSS}^{\mathrm{T}}$ was tested on a panel of Gram-negative bacteria by an agar spot inoculation test (Schillinger \& Lücke, 1989). An overnight culture $(50 \mathrm{ml})$ of the test organism was centrifuged and resuspended in 1$3 \mathrm{ml}$ YPSC medium, depending upon the size of the pellet. An aliquot $(20 \mu \mathrm{l})$ of the cell suspension was added to $3.5 \mathrm{ml}$ molten $0.6 \%$ YPSC agar and poured over the surface of YPSC agar plates (1.5\%). After the semi-solid agar had solidified, $10 \mu \mathrm{l}$ of a $24-48 \mathrm{~h}$ culture of strain JSS ${ }^{\mathrm{T}}$ was placed on the surface of the semi-solid agar. Plates were incubated at $30{ }^{\circ} \mathrm{C}$ and observed for clearing of the lawn. None of the following Gram-negative bacteria were susceptible to predation by strain $\mathrm{JSS}^{\mathrm{T}}$ : Aeromonas salmonicida, Aquaspirillum serpens, Azospirillum brasilense, Enterobacter aerogenes, Escherichia coli, Erwinia herbicola, Proteus mirabilis, Pseudomonas aeruginosa, Pseudomonas fluorescens, Pseudomonas syringae, Rhizobium leguminosarum, Salmonella sp., Shigella boydii and Shigella flexneri. Thus, strain JSS ${ }^{\mathrm{T}}$ has a very limited prey range, compared with Bdellovibrio bacteriovorus 109J (Jurkevitch et al., 2000) and other isolates (Stolp \& Starr, 1963). All C. crescentus strains that did not possess an S-layer were susceptible to predation (Table 1). C. crescentus CB2A is not susceptible to predation by Bdellovibrio bacteriovorus strain 109J or 65-S (Koval \& Hynes, 1991).

To determine the DNA base composition, late-stage cocultures were filtered $(0.45 \mu \mathrm{m})$ to remove residual prey cells. DNA isolation was performed using standard methods (Sambrook et al., 1989). The genomic DNA $\mathrm{G}+\mathrm{C}$ content was determined by thermal denaturation in $1 \times$ SSC. The $\mathrm{G}+\mathrm{C}$ content was calculated using the equation of Mandel et al. (1970) [ $\left.\mathrm{G}+\mathrm{C}=1.99\left(T_{\mathrm{m}}-66.0\right)\right]$. DNA from Escherichia coli K-12 and prey-independent Bdellovibrio bacteriovorus HI100 was used as reference DNA. The base composition of DNA from strain JSS ${ }^{\mathrm{T}}$ was $46.1 \mathrm{~mol} \% \mathrm{G}+\mathrm{C}$. The base composition of DNA prepared from Bdellovibrio bacteriovorus HI100 was $49.7 \mathrm{~mol} \%$ $\mathrm{G}+\mathrm{C}$. This value compares favourably with the published value of $50.4 \mathrm{~mol} \% \mathrm{G}+\mathrm{C}$ (Burnham \& Conti, 1984; Williams et al., 2005). The thermal denaturation curve of the DNA preparation from strain JSS ${ }^{\mathrm{T}}$ gave no indication of contaminating C. crescentus DNA (62-67 mol\% G + C; data not shown).

Schwudke et al. (2001) proposed that the genetic locus hit (for host interaction) was restricted to Bdellovibrio bacteriovorus strains and could be used as a specific probe for this species. Therefore, we screened the genomic DNA of strain $\mathrm{JSS}^{\mathrm{T}}$ for the presence of the hit locus by PCR amplification (according to Schwudke et al., 2001) and Southern blotting (as described by Flannagan et al., 2004) with a DIG-labelled hit locus probe. The hit locus was not identified in strain JSS $^{\mathrm{T}}$ by either method (data not shown). As positive controls, genomic DNA of Bdellovibrio bacteriovorus strains 109J and 6-5-S was screened. As a negative control, genomic DNA of Bacteriolyticum stolpii $\mathrm{UKi} 2^{\mathrm{T}}$ was screened. These results support the identification of strain JSS $^{\mathrm{T}}$ as a member of a novel species of Bdellovibrio.

For identification purposes, the $16 \mathrm{~S}$ rRNA gene of strain JSS $^{\mathrm{T}}$ was amplified and sequenced in almost its entire length (1432 bp) as described by Jurkevitch et al. (2000). The 16S rRNA gene sequence (Genbank accession no. EF687743) had $93 \%$ similarity to that of Bdellovibrio bacteriovorus $\mathrm{HD} 100^{\mathrm{T}}$. Other Bdellovibrio bacteriovorus isolates (strains 109J, 114, 127) had similarity values of 90-93\% to strain JSS $^{\mathrm{T}}$. Therefore, the closest relatives to strain JSS $^{\mathrm{T}}$ are members of the genus Bdellovibrio. 
A phylogenetic tree was reconstructed based on $16 \mathrm{~S}$ rRNA gene sequences. Eleven good-quality, long ( $>1200 \mathrm{bp})$, representative cultured 16S rRNA gene sequences from Bdellovibrio strains were downloaded from GenBank on October 2011 and aligned by MUSCLE (Edgar, 2004). The alignment was trimmed at both ends in order for all the sequences to overlap each other fully, and a maximumlikelihood tree was reconstructed using MEGA5 (Tamura et al., 2011), with Bacteriovorax as an outgroup. Our phylogenetic analysis confirmed that strain JSS $^{T}$ is a member of the class Deltaproteobacteria and that it belongs to the Bdellovibrio cluster (Fig. 2). It is distantly related to Bdellovibrio bacteriovorus strains, though not as distant as isolate TRA2. A more extensive phylogenetic analysis (not shown) was undertaken using all 162 good-quality, long Bdellovibrio 16S rRNA gene sequences available at the RDP-II database, from both cultured and environmental samples. This phylogenetic tree confirmed the position of strain JSS ${ }^{\mathrm{T}}$ in the Bdellovibrio lineage, and also revealed an interesting observation: the Bdellovibrio sequences split into two major clusters, one encompassing all the cultured strains alongside some sequences from uncultured organisms and another composed solely of sequences from uncultured bacteria. This suggests that many groups in this latter cluster may be very different from the 'classic' Bdellovibrio, thus providing ample opportunity for further study of the diversity of this genus.

Since the report of strain JSS $^{\mathrm{T}}$ by Koval \& Hynes (1991), more BALOs have been isolated on lawns of $C$. crescentus CB2A, this time from another sewage treatment plant in London, Ontario, Canada, and from compost samples. These strains (KL1 to 8) had similar properties to strain JSS $^{\mathrm{T}}$ : extracellular attachment, no bdelloplast formation and no lysis of Escherichia coli ML35 (Shemesh et al., 2003). The partial sequence of the 16S rRNA gene of strain KL8 (GenBank accession no. JQ080553) showed $99 \%$ similarity to the 16S rRNA gene sequence of strain JSS ${ }^{\mathrm{T}}$.

A summary of the phenotypic characteristics of strain JSS ${ }^{\mathrm{T}}$ and Bdellovibrio bacteriovorus $\mathrm{HD} 100^{\mathrm{T}}$ is provided in Table

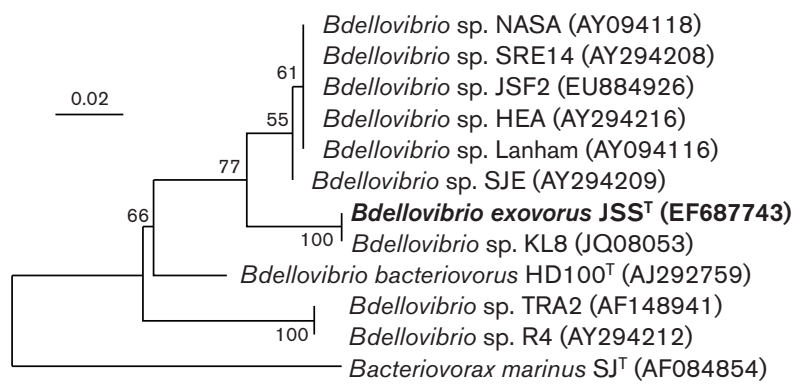

Fig. 2. Phylogenetic tree of the Bdellovibrionales based on $16 \mathrm{~S}$ rRNA gene sequences, showing the position of strain $\mathrm{JSS}^{\top}$ in the genus Bdellovibrio. Bootstrap values $(>50 \%$ ) based on 1000 replicates are shown at branch nodes. Bar, 0.02 substitutions per nucleotide position.
2. Strain $\mathrm{JSS}^{\mathrm{T}}$ lacks an intracellular, periplasmic growth phase, and no bdelloplast is formed during the life cycle. The prey range, as studied so far, is limited to C. crescentus. Additional chemotaxonomic data would be useful to support this proposal for a novel species of Bdellovibrio. However, these analyses need to be done with preyindependent mutants of predators, a rationale stated by Schwudke et al. (2001). The presence of remaining prey cells in a co-culture necessitates their separation from predators by filtration or differential centrifugation. This is not an easy task, especially on a large scale. Caution would have to be exercised in interpretation of chemotaxonomic data from prey-independent mutants, as the chemical composition of mutants may not be the same as that of the wild-type strain. Furthermore, analyses of properties such as fatty acid composition need to be conducted under standardized conditions, as the results vary with experimental conditions (temperature, growth stage, growth medium). For BALOs, the chemical composition of cells may also vary between the attack and growth phases.

Strain JSS ${ }^{\mathrm{T}}$ differs from Bdellovibrio bacteriovorus as it does not demonstrate a periplasmic growth stage or form bdelloplasts. Strain JSS ${ }^{\mathrm{T}}$ therefore represents a novel species, for which the name Bdellovibrio exovorus sp. nov. is proposed.

\section{Description of Bdellovibrio exovorus sp. nov.}

Bdellovibrio exovorus (ex.o.vo'rus. Gr. pref. exo- outside; L. v. vorare to devour, to consume; L. suff. -vorus eating; N.L. masc. adj. exovorus eating outside, referring to the epibiotic life cycle).

Gram-negative, comma-shaped rods $(0.5 \mu \mathrm{m}$ wide, $0.5-$ $1.4 \mu \mathrm{m}$ long) with a single, polar, sheathed flagellum (29 $\mathrm{nm}$ wide). Obligate predator; the type strain was isolated from sewage in enrichment cultures with Caulobacter crescentus CB2A. Does not prey on Escherichia coli. Cells exhibit a biphasic life cycle: a free swimming attack phase and a growth phase whereby the predator attaches to and remains on the outside of the prey cell. There is no periplasmic stage within the prey cell. No bdelloplast is formed. Empty stalked C. crescentus cells remain after predation is complete. Small plaques are formed on lawns

Table 2. Phenotypic characteristics of strain $\mathrm{JSS}^{\top}$ and Bdellovibrio bacteriovorus $\mathrm{HD} 100^{\top}$

Both strains form vibroid cells with a single, polar, sheathed flagellum and both strains form plaques.

\begin{tabular}{|c|c|c|}
\hline Characteristic & Strain JSS ${ }^{\mathrm{T}}$ & $\begin{array}{c}\text { B. bacteriovorus } \\
\text { HD100 }^{\mathrm{T}}\end{array}$ \\
\hline Width of flagellum (nm) & 29 & 28 \\
\hline Intracellular growth & - & + \\
\hline Bdelloplast formation & - & + \\
\hline Prey range & Caulobacter & Wide \\
\hline
\end{tabular}


of prey cells. Growth is by binary fission while attached to the prey cell. On the basis of $16 \mathrm{~S}$ rRNA gene sequence similarity, belongs to the class Deltaproteobacteria, related to Bdellovibrio bacteriovorus ( $93 \%$ similarity). Differs from Bdellovibrio bacteriovorus as it does not demonstrate a periplasmic growth stage or form bdelloplasts.

The type strain, JSS $^{\mathrm{T}} \quad\left(=\mathrm{ATCC}\right.$ BAA $-2330^{\mathrm{T}}=\mathrm{DSM}$ $25223^{\mathrm{T}}$ ), was isolated from sewage in enrichment cultures with Caulobacter crescentus CB2A. Similar isolates were obtained from compost and soil. The DNA G + C content of the type strain is $46.1 \mathrm{~mol} \%$.

\section{Acknowledgements}

We thank Jeanne Poindexter and John Smit for the generous gifts of Caulobacter strains, Ken Jarrell (Queen's University, Kingston, Ontario) for the DNA base composition analysis and R. G. E. Murray (University of Western Ontario, London, Ontario) for continued interest and assistance with nomenclature. The technical assistance of Paul Fox, Patrick Keeling, Christina Tieszer, Kyle Cullingham, Krista Lyle, Dianne Moyles, Judy Sholdice and Ryan Chanyi is greatly appreciated. Colleen Janssen, a student from Regina Mundi High School in London, assisted with the prey range studies as part of a Cooperative Education Program in Science (London and Middlesex County Roman Catholic School Board). TEM was performed in the Transmission Electron Microscopy facility in the Department of Microbiology and Immunology at the University of Western Ontario. SEM was done at the Surface Science Western facility at the University of Western Ontario. This research was supported by an operating grant from the former Medical Research Council of Canada to S. F. K. and R. G. E. Murray and a Discovery Grant to S. F. K. from the Natural Sciences and Engineering Research Council of Canada (NSERC).

\section{References}

Baer, M. L., Ravel, J., Chun, J., Hill, R. T. \& Williams, H. N. (2000). A proposal for the reclassification of Bdellovibrio stolpii and Bdellovibrio starrii into a new genus, Bacteriovorax gen. nov. as Bacteriovorax stolpii comb. nov. and Bacteriovorax starrii comb. nov., respectively. Int J Syst Evol Microbiol 50, 219-224.

Burnham, J. C. \& Conti, S. F. (1984). Genus Bdellovibrio. In Bergey's Manual of Systematic Bacteriology, vol. 1, pp. 118-124. Edited by N. R. Krieg \& J. G. Holt. Baltimore: Williams \& Wilkins.

Burnham, J. C., Hashimoto, T. \& Conti, S. F. (1968). Electron microscopic observations on the penetration of Bdellovibrio bacteriovorus into gram-negative bacterial hosts. J Bacteriol 96, 13661381.

Cotter, T. W. \& Thomashow, M. F. (1992). A conjugation procedure for Bdellovibrio bacteriovorus and its use to identify DNA sequences that enhance the plaque-forming ability of a spontaneous hostindependent mutant. J Bacteriol 174, 6011-6017.

Davidov, Y. \& Jurkevitch, E. (2004). Diversity and evolution of Bdellovibrio-and-like organisms (BALOs), reclassification of Bacteriovorax starrii as Peredibacter starrii gen. nov., comb. nov., and description of the Bacteriovorax-Peredibacter clade as Bacteriovoracaceae fam. nov. Int J Syst Evol Microbiol 54, 1439-1452.

Davidov, Y., Huchon, D., Koval, S. F. \& Jurkevitch, E. (2006). A new $\alpha-$ proteobacterial clade of Bdellovibrio-like predators: implications for the mitochondrial endosymbiotic theory. Environ Microbiol 8, 21792188.
Edgar, R. C. (2004). MUSCLE: multiple sequence alignment with high accuracy and high throughput. Nucleic Acids Res 32, 1792-1797.

Flannagan, R. S., Valvano, M. A. \& Koval, S. F. (2004). Downregulation of the motA gene delays the escape of the obligate predator Bdellovibrio bacteriovorus 109J from bdelloplasts of bacterial prey cells. Microbiology 150, 649-656.

Johnson, R. C. \& Ely, B. (1977). Isolation of spontaneously derived mutants of Caulobacter crescentus. Genetics 86, 25-32.

Jurkevitch, E. (2006). The genus Bdellovibrio. In The Prokaryotes: a Handbook on the Biology of Bacteria, 3rd edn, vol. 7, pp. 12-30. Edited by M. Dworkin, S. Falkow, E. Rosenberg, K. H. Schleifer \& E. Stackebrandt. New York: Springer.

Jurkevitch, E., Minz, D., Ramati, B. \& Barel, G. (2000). Prey range characterization, ribotyping, and diversity of soil and rhizosphere Bdellovibrio spp. isolated on phytopathogenic bacteria. Appl Environ Microbiol 66, 2365-2371.

Koval, S. F. \& Hynes, S. H. (1991). Effect of paracrystalline protein surface layers on predation by Bdellovibrio bacteriovorus. J Bacteriol 173, 2244-2249.

Mandel, M., Igambi, L., Bergendahl, J., Dodson, M. L., Jr \& Scheltgen, E. (1970). Correlation of melting temperature and cesium chloride buoyant density of bacterial deoxyribonucleic acid. J Bacteriol 101, 333-338.

Piñeiro, S. A., Williams, H. N. \& Stine, O. C. (2008). Phylogenetic relationships amongst the saltwater members of the genus Bacteriovorax using $r p o B$ sequences and reclassification of Bacteriovorax stolpii as Bacteriolyticum stolpii gen. nov., comb. nov. Int J Syst Evol Microbiol 58, 1203-1209.

Sambrook, J., Fritsch, E. F. \& Maniatis, T. (1989). Molecular Cloning: a Laboratory Manual, 2nd edn. Cold Spring Harbor, NY: Cold Spring Harbor Laboratory.

Schillinger, U. \& Lücke, F.-K. (1989). Antibacterial activity of Lactobacillus sake isolated from meat. Appl Environ Microbiol 55, 1901-1906.

Schwudke, D., Strauch, E., Krueger, M. \& Appel, B. (2001). Taxonomic studies of predatory bdellovibrios based on 16S rRNA analysis, ribotyping and the hit locus and characterization of isolates from the gut of animals. Syst Appl Microbiol 24, 385-394.

Seidler, R. J. \& Starr, M. P. (1969). Isolation and characterization of host-independent bdellovibrios. J Bacteriol 100, 769-785.

Seidler, R. J., Mandel, M. \& Baptist, J. N. (1972). Molecular heterogeneity of the bdellovibrios: evidence of two new species. J Bacteriol 109, 209-217.

Shemesh, Y., Davidov, Y., Koval, S. F. \& Jurkevitch, E. (2003). Small eats big: ecology and diversity of Bdellovibrio and like organisms, and their dynamics in predator-prey interactions. Agronomie 23, 433439.

Snyder, A. R., Williams, H. N., Baer, M. L., Walker, K. E. \& Stine, O. C. (2002). 16S rDNA sequence analysis of environmental Bdellovibrioand-like organisms (BALO) reveals extensive diversity. Int J Syst Evol Microbiol 52, 2089-2094.

Starr, M. P. \& Baigent, N. L. (1966). Parasitic interaction of Bdellovibrio bacteriovorus with other bacteria. J Bacteriol 91, 20062017.

Stolp, H. \& Starr, M. P. (1963). Bdellovibrio bacteriovorus gen. et sp. n., a predatory, ectoparasitic, and bacteriolytic microorganism. Antonie van Leeuwenhoek 29, 217-248.

Tamura, K., Peterson, D., Peterson, N., Stecher, G., Nei, M. \& Kumar, S. (2011). MEGA5: molecular evolutionary genetics analysis using maximum likelihood, evolutionary distance, and maximum parsimony methods. Mol Biol Evol 28, 2731-2739. 
Thomashow, M. F. \& Rittenberg, S. C. (1978). Intraperiplasmic growth of Bdellovibrio bacteriovorus 109J: solubilization of Escherichia coli peptidoglycan. J Bacteriol 135, 998-1007.
Williams, H. N., Baer, M. L. \& Tudor, J. J. (2005). Genus I. Bdellovibrio. In Bergey's Manual of Systematic Bacteriology, 2nd edn, vol. 2, pp. 1041-1053. Edited by D. J. Brenner, N. R. Krieg \& J. T. Staley. New York: Springer. 